\title{
Disturbance, colonial fragmentation, and size- dependent life history variation in two coral reef cnidarians*
}

\author{
Ronald H. Karlson \\ Ecology and Organismic Biology Program, School of Life and Health Sciences, University of Delaware, Newark, Delaware
} 19716, USA

\begin{abstract}
Fragmentation can be a crucial part of the life history of colonial invertebrates inhabiting disturbed environments. In some colonial species, fragments may be generated solely by external forces. In others, fragmentation may be facilitated by the degeneration of skeletal or soft-tissue connections between individuals. Colonies of 2 abundant coral reef zoanthid species, Zoanthus sociatus and $Z$. solanderi, occur as highly fragmented aggregations of polyps with mean sizes between 1.7 and 4.5 polyps per fragment. These are among the smallest fragments for colonial species which maintain connections with their asexual offspring. These data are consistent with the notion that at least some of the fragmentation in these species is under endogenous control. In spite of living in a physically more benign habitat, $Z$. solanderi had more highly fragmented colonies than did $Z$. sociatus. Generally, the life history of fragmenting colonial invertebrates includes high colony mortality and delay of sexual reproduction among small colonies. Colony size-specific data from $Z$. sociatus conform with these expectations. $Z$. solanderi, on the other hand, appears to have reduced some of the usual costs associated with small colony size. It exhibited lower size-dependent mortality than did $Z$. sociatus and underwent some sexual reproduction among small colonies. The adaptive trade-off between colonial fragmentation and integration may involve a balance between local and much larger scale sources of mortality. Major catastrophic events are likely to favor genet fragmentation and the spreading of risk. The degree of fragmentation, however, may be limited by small-scale, sizedependent mortality.
\end{abstract}

\section{INTRODUCTION}

Characteristic growth and life history traits are common to a variety of sessile, marine invertebrates which inhabit disturbed environments (Jackson 1979, Suchanek 1981, Bell 1982, Highsmith 1982). Such traits include the capacity to regenerate following injury (Jackson 1977, Jackson \& Palumbi 1979, Karlson 1983, Wahle 1983) and genet fragmentation among colonial invertebrates (Highsmith 1982). The life history of sessile, colonial organisms includes larval mortality, larval settlement, and adult mortality as in solitary organisms. In addition, colonial organisms can bud, undergo fission, and disperse as viable colony fragments (e.g. Highsmith 1980, Lasker 1984). Colonial organisms can

\footnotetext{
- Contribution No. 348 from the Discovery Bay Marine Laboratory, University of the West Indies, Discovery Bay, Jamaica
}

also survive the loss of some, but not all, of the individuals within a given colony (Hughes \& Jackson 1980, 1985, Hughes 1984). The population dynamics of such organisms are often highly dependent on colony size (Buss 1980, 1981, Sebens 1982a, Hughes 1984). Therefore, fragmentation can be an extremely important life history process because of its direct effect on the size of colony fragments (Connell 1973, Hughes \& Jackson 1980, 1985, Highsmith 1982, Wahle 1983, Hughes 1984, Lasker 1984).

Generally, among fragmenting colonial species, one finds that large fragments have higher survivorship than do small fragments (Connell 1973, Hughes \& Jackson 1980, Highsmith 1982, Hughes 1984). Species may avoid the high energetic cost of producing many sexual offspring or small colony fragments having low survivorship by asexually producing large fragments with high survivorship (Highsmith 1982). Small colonies of such species should delay the onset of sexual 
reproduction and allocate relatively little energy to the sexual process (i.e. have low reproductive effort) until they reach some larger size (Highsmith 1982).

I have examined 2 closely related coral reef cnidarian species in order to evaluate these expected life history patterns. These species are Zoanthus sociatus (Ellis) and $Z$. solanderi Lesueur (Class Anthozoa, Order Zoanthidea). They are soft-bodied, stoloniferous, clonal organisms which commonly form large, nearly monospecific aggregations of many colonies on Caribbean coral reefs (Goreau 1959, Kinzie 1973, Sebens 1982b, Karlson 1983). Their densities can exceed $1 \times 10^{4}$ polyps $\mathrm{m}^{-2}$ (Karlson 1983) as they typically cover the unconsolidated coral rubble substratum. Generally, $Z$. sociatus is a dominant inhabitant of low intertidal and shallow subtidal zones (Goreau 1959, Kinzie 1973, Sebens 1982b, Karlson 1983), is subjected to greater wave action and intertidal exposure (Karlson 1980, 1983, Sebens 1982b, Fadlallah et al. 1984), and is more resistant to intertidal desiccation than $Z$. solanderi (Sebens 1982b). The lower depth distribution of $Z$. solanderi results in greater exposure to subtidal predators (Sebens 1982b, Karlson 1983) and competitors (Karlson 1980). Correspondingly, Z. solanderi displays greater resistance to predation (Sebens 1982b) and overgrowth (Karlson 1980).

Colonial fragments among stoloniferous zoanthids can be generated by at least 2 processes: endogenous, stolonal degeneration (West 1979, Muirhead \& Ryland 1985) and exogenous, storm-related turbulence (Karlson 1983). In Zoanthus sociatus and $Z$. solanderi, stolonal degeneration results in fragments composed of single polyps or groups of connected polyps located within a colony. Fragmentation by this process does not directly result in fragment dispersal but it is likely to facilitate dispersal during storms. Storm-related turbulence may fragment and disperse single polyps, groups of connected polyps, and even unconnected, mixed-clonal groups of polyps sharing a common substratum. These fragments can collect in relatively low energy microhabitats forming large aggregations or they can be dispersed to more isolated locations. The survivorship of isolated fragments is highly sizedependent as illustrated by the 2 fragmentation experiments described below.

\section{METHODS}

During June and August 1983 and January 1984, 217 zoanthid colonies were collected on reefs at Discovery Bay, Jamaica. These collections included completely sampled, isolated colonies of 1 to 60 polyps each and subsamples of 50 contiguous polyps taken from very large zoanthid aggregations (Table 1). Care was taken to minimize any damage to stolonal connections between polyps. All collected zoanthids were preserved in $4 \%$ formaldehyde in seawater and were examined later under magnification. Each colony was carefully dissected one polyp at a time in order to locate stolonal connections and to determine the number of polyps in each group of connected individuals. Each polyp was then bisected and all coelenteric mesenteries were examined for the presence of large $(>50 \mu \mathrm{m})$ ova or spermaria.

In order to test for colony size-dependent variation in

Table 1. Zoanthus sociatus and Z. solanderi. Mean fragment size and relative frequency of fertile polyps in 217 zoanthid samples

\begin{tabular}{|c|c|c|c|c|c|c|c|c|c|c|}
\hline \multirow{2}{*}{$\begin{array}{l}\text { Colony } \\
\text { size } \\
\text { (polyps) }\end{array}$} & \multirow[t]{2}{*}{$\begin{array}{l}\text { Sample } \\
\text { date }\end{array}$} & \multirow[t]{2}{*}{ Species } & \multirow{2}{*}{$\begin{array}{c}\text { Number of } \\
\text { sampled } \\
\text { colonies }\end{array}$} & \multicolumn{3}{|c|}{ Mean fragment size } & \multicolumn{2}{|c|}{$\begin{array}{c}t \text { test } \\
\mathrm{H}_{0}: \mu=1.0\end{array}$} & \multicolumn{2}{|c|}{$\begin{array}{l}\text { Relative } \\
\text { frequency of } \\
\text { fertile polyps }\end{array}$} \\
\hline & & & & (Polyps) & $( \pm S E)$ & fragments) & (t) & (p) & $\begin{array}{l}\text { tertile } \\
(\%)\end{array}$ & $\begin{array}{l}\text { (Tolyps } \\
\text { polyps) }\end{array}$ \\
\hline \multirow[t]{2}{*}{$1-60$} & Jun 83 & $\begin{array}{l}Z \text { Z. sociatus } \\
Z \text {. solanderi }\end{array}$ & $\begin{array}{l}36 \\
45\end{array}$ & $\begin{array}{l}4.4 \\
2.4\end{array}$ & $\begin{array}{l}0.51 \\
0.11\end{array}$ & $\begin{array}{r}89 \\
151\end{array}$ & $\begin{array}{r}6.67 \\
12.73\end{array}$ & $\begin{array}{l}<0.001 \\
<0.001\end{array}$ & $\begin{array}{c}0 \\
10.9\end{array}$ & $\begin{array}{l}388 \\
359\end{array}$ \\
\hline & $\operatorname{Jan} 84$ & $\begin{array}{l}Z \text { Z. sociatus } \\
Z \text {. solanderi }\end{array}$ & $\begin{array}{l}37 \\
39\end{array}$ & $\begin{array}{l}4.5 \\
2.5\end{array}$ & $\begin{array}{l}0.52 \\
0.15\end{array}$ & $\begin{array}{r}86 \\
155\end{array}$ & $\begin{array}{r}6.73 \\
10.00\end{array}$ & $\begin{array}{l}<0.001 \\
<0.001\end{array}$ & $\begin{array}{l}0 \\
0\end{array}$ & $\begin{array}{l}389 \\
392\end{array}$ \\
\hline \multirow[t]{3}{*}{$>10000$} & Jun 83 & $\begin{array}{l}Z . \text { sociatus } \\
Z \text {. solanderi }\end{array}$ & $\begin{array}{l}10^{\circ} \\
10^{\circ}\end{array}$ & $\begin{array}{l}2.3 \\
1.7\end{array}$ & $\begin{array}{l}0.11 \\
0.06\end{array}$ & $\begin{array}{l}217 \\
301\end{array}$ & $\begin{array}{l}11.82 \\
11.67\end{array}$ & $\begin{array}{l}<0.001 \\
<0.001\end{array}$ & $\begin{array}{l}21.0 \\
35.8\end{array}$ & $\begin{array}{l}500 \\
500\end{array}$ \\
\hline & Aug 83 & $\begin{array}{l}\text { Z. sociatus } \\
\text { Z. solanderi }\end{array}$ & $\begin{array}{l}10^{\circ} \\
10^{\circ}\end{array}$ & $\begin{array}{l}- \\
-\end{array}$ & - & - & $\begin{array}{l}- \\
-\end{array}$ & $\begin{array}{l}- \\
-\end{array}$ & $\begin{array}{l}27.0 \\
32.4\end{array}$ & $\begin{array}{l}500 \\
500\end{array}$ \\
\hline & Jan 84 & $\begin{array}{l}Z \text {. sociatus } \\
Z \text {. solanderi }\end{array}$ & $\begin{array}{l}10^{\circ} \\
10^{\circ}\end{array}$ & $\begin{array}{l}- \\
-\end{array}$ & - & - & - & $\begin{array}{l}- \\
-\end{array}$ & $\begin{array}{l}1.6 \\
0\end{array}$ & $\begin{array}{l}500 \\
500\end{array}$ \\
\hline
\end{tabular}


survivorship, a fragmentation experiment was begun in July 1983. Thirty zoanthid colonies were collected with their coral rubble substratum, trimmed to an appropriate size $(1,10$, or 100 to 200 polyps) using a scalpel, and secured to a 3 inch $(7.6 \mathrm{~cm})$ mesh nylon net which was tied down onto a rubble bottom at a depth of $2 \mathrm{~m}$ within each of 2 collecting sites. One site in the lee of One Palm Island, Discovery Bay, was dominated by Zoanthus sociatus (Karlson 1983) and the other at the East Back Reef by Z. solanderi (Karlson $1980,1981)$. Generally this latter site has been considered to be more protected from wave energy than the former (Karlson 1983). By experimentally fragmenting and moving zoanthid colonies, I have attempted to simulate the effects of exogenous, storm-related fragmentation and the dispersal of isolated colonies. These colonies were examined after 1 yr during July 1984

In January 1984, a reciprocal transplant version of the above experiment was conducted to determine if habitat differences between the 2 sites might account for species and size-dependent variation in colony survivorship. Forty colonies of each species in one of 2 size classes (1 or 10 polyps) were collected. Zoanthus sociatus was collected from the One PaIm Island site, Z. solanderj from the East Back Reef. Half of each species and size class were moved to each experimental site and secured as described above. These colonies were examined after 6 mo during July 1984.

\section{RESULTS}

The data clearly document that large and small zoanthid colonies were composed of many small groups of connected polyps. Given their small size, these groups are likely to have been formed primarily by stolonal degeneration, but some may also have resulted from the growth of recently settled larvae or by the aggregative settlement of fragments created during storms. Regardless of origin, I refer here to these groups of polyps as fragments. The mean fragment sizes ranged between 1.7 and 4.5 polyps per fragment (Table 1). Comparisons between species and size classes indicate that Zoanthus solanderi had significantly smaller fragments than did $Z$. sociatus and large colonies of both species had significantly smaller fragments than did small colonies (t tests, $p<0.001$, data in Table 1). Some, but certainly not all, of these latter differences may be due to damage to stolonal connections during the subsample collections from the large colonies. However, even the highest mean fragment size was quite low for such long-lived, clonal organisms (Karlson 1980, 1983) which reach relatively stable, high densities (Karlson 1983) and have a potential for doubling polyp number every $30 \mathrm{~d}$ (Sebens
$1982 \mathrm{~b}$. In fact, these fragment sizes are near, yet significantly different from, the lower limit (i.e. single polyps) for colonial organisms (Table 1).

The survivorship of fragmented zoanthid colonies was found to be highly dependent on colony size (Table 2). In the first fragmentation experiment, significantly lower survivorship was evident after 1 yr in the small colony size classes $\left(\chi^{2}=10.00\right.$, d.f. $=2$, $\mathrm{p}<0.01$ ). In addition, survivorship was significantly lower in Zoanthus sociatus than in $Z$. solanderi $\left(\chi^{2}=\right.$ 5.08 , d.f. $=1, p<0.025)($ Table 2$)$. Sources of polyp loss included predation by the polychaete Hermodice carunculata (Pallus) and the damselfish Eupomacentrus planifrons Cuvier, overgrowth by the encrusting gorgonian Erythropodium caribaeorum (Duch. \& Mich.), crushing by dislodged coral rubble, and dispersal of some colony fragments.

Survivorship in the second fragmentation experiment was considerably lower than in the first (Table 2). This was probably caused by the large increase in macroalgae on the reef following the mass mortality of Diadema antillarum Philippi (Lessios et al. 1984). This macroalgal cover appeared to result in crowding and possibly overgrowth of small zoanthid colonies. After 6 mo, a significantly higher proportion of Zoanthus sociatus colonies had died than had those of $Z$. solanderi $\left(\chi^{2}=12.57\right.$, d.f. $=1, p<0.001$, Table 2$)$ and more of the mortality occurred in the smaller size class $\left(\chi^{2}=\right.$ 11.59, d.f. $=1, p<0.001$, Table 2). In spite of apparent habitat differences, there was no significant habitat effect on colony survivorship $\left(\chi^{2}=0.83\right.$, d.f. $=1$, $p>0.50$, Table 2).

These experiments clearly establish significant sizedependent survivorship. There were also size-dependent differences in zoanthid sexual reproductive patterns. During the summer of 1983, the subsamples from large aggregations of both species indicate that 21.0 to $35.8 \%$ of the polyps were fertile (bearing ova, spermaria, or both) (Table 1). However, among small colonies (<60 polyps), only Zoanthus solanderi underwent gametogenesis. Although the relative frequency of fertile polyps in these small colonies was only $10.9 \%$, it was significantly greater than the $0 \%$ observed for $Z$. sociatus $\left(\chi^{2}=40.88\right.$, d.f. $=1$, $\mathrm{p}<0.001$ ) (Table 1). The absence of gametogenesis in small colonies if $Z$. sociatus suggests that this species delays sexual reproduction until reaching some larger colony size.

\section{DISCUSSION}

These data support the generalization that, among fragmenting species, small colonies experience higher mortality rates than larger colonies (Connell 1973, 
Table 2. Zoanthus sociatus and $Z$. solanderi. Size-dependent survivorship of zoanthid colonies at One Palm Island (1PI) and East Back Reef (EBR) sites at Discovery Bay. Jamalca

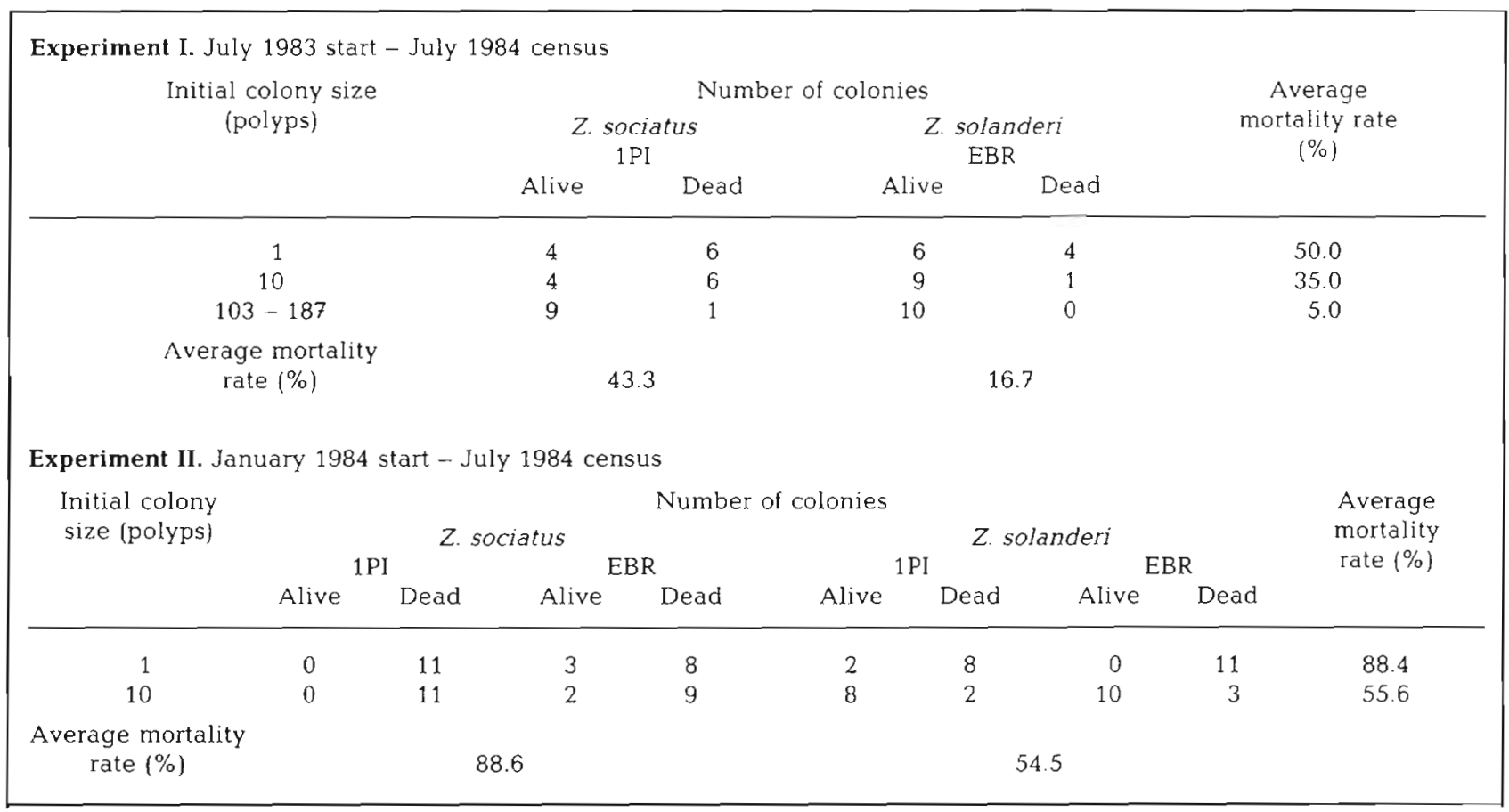

Highsmith 1982). Delayed sexual reproduction was characteristic of Zoanthus sociatus, but not of $Z$. solanderi. Early gametogenesis and the lower mortality rate in $Z$. solanderi (see also Sebens $1982 \mathrm{~b}$ ) suggest that this species has evolved adaptations which reduce some of the usual costs associated with small colony size. Although one might expect $Z$. sociatus to exhibit significantly higher growth rates than $Z$. solanderi in order to compensate for its lower survivorship, growth rates for these 2 species do not appear to differ significantly (Sebens 1982b, Karlson unpubl.).

Fragmentation within zoanthid colonies results in some of the lowest possible levels of integration exhibited by clonal organisms which maintain connections with their asexual offspring. Although low levels of integration occur among living scleractinians (Coates \& Oliver 1973), alcyonarians (Bayer 1973), bryozoans (McKinney 1984), and a variety of other clonal organisms (Boardman et al. 1973, Jackson 1977, Pitelka 1984), most colonial invertebrates exhibit much higher levels of integration than do these zoanthids.

The selective regime affecting this level of integration, and conversely fragmentation, is likely to include both small-scale, local sources of mortality and largescale, catastrophic events. The latter are more likely to favor colonial fragmentation and the spreading of the risk of genet mortality (den Boer 1968, Highsmith, 1982); high levels of colonial integration (i.e. large unfragmented colonies) are likely to be maladaptive.
On the other hand, the high mortality typically experienced by very small colonies suggests a possible limit to the degree of fragmentation; extreme fragmentation may be too costly because of size-dependent mortality among dispersed colony fragments.

Acknowledgements. I thank the staff of the Discovery Bay Marine Laboratory for their assistance and the use of their facility. I also thank G. Bruno, M. Shenk, D. Levitan, and M. Chintala for assistance in the field and M. Chintala, J. Cohen, and B. Naylor for their hours spent in the laboratory. A. Butler, L. Hurd, D. Levitan, M. Shenk, and 3 anonymous reviewers made numerous helpful comments on versions of this manuscript. Final revisions were facilitated by $\mathrm{A}$. Butler and the Department of Zoology, University of Adelaide. This research was funded by NSF grant no. OCE-8214847.

\section{LITERATURE CITED}

Bayer, F. M. (1973). Colonial organization in octocorals. In: Boardman, R. S., Cheetham, A. H., Oliver, Jr., W. A. (ed.) Animal colonies. Development and function through time. Dowden, Hutchinson \& Ross, Inc., Stroudsburg, p. 69-93

Bell, G. (1982). The masterpeice of nature. The evolution and genetics of sexuality. University of California Press, Berkeley

Boardman, R. S., Cheetham, A. H., Oliver, Jr., W. A. (ed.) (1973). Animal colonies. Development and function through time. Dowden, Hutchinson \& Ross, Inc., Stroudsburg

Buss, L. W. (1980). Competitive intransitivity and size-frequency distributions of interacting populations. Proc. Natn. Acad. Sci. U.S.A. $77: 5355-5359$ 
Buss, L. W. (1981). Group living, competition, and the evolution of cooperation in a sessile invertebrate. Science 213 1012-1014

Coates, A. G., Oliver, Jr., W. A. (1973). Coloniality in zoantharian corals. In: Boardman, R. S., Cheetham, A. H., Oliver, Jr., W. A. (ed.) Animal colonies. Development and function through time. Dowden, Hutchinson \& Ross, Inc. Stroudsburg, p. 3-27

Connell, J. H. (1973). Population ecology of reef-building corals. In: Jones, O. A., Endean, R. (ed.) Biology and geology of coral reefs, Vol. 2, Biol. 1. Academic Press, New York, p. 205-245

den Boer, P. J. (1968). Spreading of risk and stabilization of animal numbers. Acta Biotheor. 18: 165-194

Fadlallah, Y. H., Karlson, R. H., Sebens, K. P. (1984). A comparative study of sexual reproduction in three species of Panamanian zoanthids (Coelenterata: Anthozoa). Bull. mar. Sci. 35: 80-89

Goreau, T F. (1959). The ecology of Jamaican coral reefs. I. Species composition and zonation. Ecology 40: 67-90

Highsmith, R. C. (1980). Passive colonization and asexual colony multiplication in the massive coral Porites lutea Milne Edwards \& Haime. J. exp. mar. Biol. Ecol. 47: 55-67

Highsmith, R. C. (1982). Reproduction by fragmentation in corals. Mar. Ecol. Prog. Ser. 7: 207-226

Hughes, I. P. (1984). Population dynamics based on individual size rather than age: a general model with a reef coral example. Am. Nat. 123: 778-795

Hughes, T. P., Jackson, J. B. C. (1980). Do corals lie about their age? Some demographic consequences of partial mortality, fission and fusion. Science 209: 713-715

Hughes, T. P., Jackson, J. B. C. (1985). Population dynamics and life histories of foliaceous corals. Ecol. Monogr. 55: $141-166$

Jackson, J. B. C. (1977). Competition on marine hard substrata: the adaptive significance of solitary and colonial strategies. Am. Nat. 111: 743-767

Jackson, J. B. C. (1979). Morphological strategies of sessile organisms. In: Larwood, G. P., Rosen, B. R. (ed.) Biology and systematics of colonial organisms. Academic Press, London, p. 499-555

Jackson, J. B. C., Palumbi, S. R. (1979). Regeneration and partial predation in cryptic coral reef environments: pre- liminary experiments on sponges and ectoprocts. Colloques int. Cent. Natn. Rech. Scient. 291: 303-308

Karlson, R. H. (1980). Alternative competitive strategies in a periodically disturbed habitat. Bull. mar. Sci. 30: 894-900

Karlson, R. H. (1981). Reproductive patterns in Zoanthus spp. from Discovery Bay, Jamaica. Proc. 4th Int. Coral Reef Symp., Vol. 2. Marine Sciences Center, Univ. Philippines, Quezon City, p. 699-704

Karlson, R. H. (1983). Disturbance and monopolization of a spatial resource by Zoanthus sociatus (Coelenterata Anthozoa) Bull. mar. Sci. 33: 118-131

Kinzie, R. A. (1973). The zonation of West Indian gorgonians Bull. mar. Sci. 23: 93-155

Lasker, H. R. (1984). Asexual reproduction, fragmentation, and skeletal morphology of a plexaurid gorgonian. Mar Ecol. Prog. Ser. 19: 261-268

Lessios, H. A., Robertson, D. R., Cubit, J. D. (1984). Spread of Diadema mass mortality through the Caribbean. Science 226: 335-337

McKinney, F. K. (1984). Feeding currents of gymnolaemate bryozoans: better organization with higher colonial integration. Bull. mar. Sci. 34: 315-319

Muirhead, A., Ryland, J. S. (1985). A review of the genus Isaurus Gray, 1828 (Zoanthidea), including new records from Fiji. J. nat. Hist. 19: 323-335

Pitelka, L. F. (1984). Application of the $-3 / 2$ power law to clonal herbs. Am. Nat. 123: 442-449

Sebens, K. P. (1982a). Competition for space: growth rate, reproductive output, and escape in size. Am. Nat. 120 189-197

Sebens, K. P. (1982b). Intertidal distribution of zoanthids on the Caribbean coast of Panama: effects of predation and desiccation. Bull. mar Sci. 32: 316-335

Suchanek, T H. (1981). The role of disturbance in the evolution of life history strategies in the intertidal mussels Mytilus edulis and Mytilus californianus. Oecologia (Berl.) 50: 143-152

Wahle, C. M. (1983). Regeneration of injuries among Jamaican gorgonians: the roles of colony physiology and environment. Biol. Bull. mar biol. Lab., Woods Hole 165 : 778-790

West, D. A. (1979). Symbiotic zoanthids (Anthozoa: Cnidaria) of Puerto Rico. Bull. mar. Sci. 29: 253-271 